\title{
Stage of Takeoff Based on Rostow's Theory for the Role of Manufacture of Non-metals, Except Petroleum and Coal Manufacture to the Economic Increase
}

\author{
Iskandar Muda ${ }^{1}$, Nurlina $^{2}$, Erlina $^{1} \&$ Tengku Erry Nuradi ${ }^{1}$ \\ ${ }^{1}$ Faculty of Economics and Business, Universitas Sumatera Utara, Medan, Indonesia \\ ${ }^{2}$ Faculty of Economic and Business, Universitas Samudra, Langsa, Indonesia \\ Correspondence: Iskandar Muda, Faculty of Economics and Business, Universitas Sumatera Utara, Medan, \\ Indonesia. E-mail: iskandar1@usu.ac.id
}

Received: April 11, 2020

doi:10.5430/rwe.v11n5p177
Accepted: May 21, 2020

Online Published: September 3, 2020

URL: https://doi.org/10.5430/rwe.v11n5p177

\begin{abstract}
This study aims to know the effect of Manufacture of Non Metalic, Except Petroleum \& Coal and Manufacture of Basic Metals to the Economic Growth based on Stage of Takeoff on Rostow's Theory. Type of research is Causal Design approach. Type of data is secondary data from Government Statistics Agency Republic of Indonesia period in years 2000 until 2015. The method of analysis used Smart PLS software. The Findings of this research are Manufacture of Non Metalic, Except Petroleum \& Coal and Manufacture of Basic Metals variables influence to the Economic Increase. The Impact of this study is not analyzed with the approach of data pooling and cross section model so that the coefficients of each equation can be known each year so it can be known which has a big influence on Economic Increase. This research has implications for the government to provide facilities and facilities to investors who want to enter in the field of Manufacture of Non-Metalic, Except Petroleum \& Coal and Manufacture of Basic Metals. The value of this research has a good value because it is measurement from 2000 until 2015 periods.
\end{abstract}

Keywords: manufacture of non metalic, except petroleum, basic metals, economic increase

JEL Code: N55, O13, Q13

\section{Introduction}

The process of economic development does not happen by itself, but it requires consistent efforts from various parties to provide the greatest prosperity for mankind. The main objective of economic development is to build capital equipment on a sufficient scale to increase productivity in agriculture, mining, plantation and industry (Saerofi, 2005 \& Lodde, 2007). Capital is also required to establish schools, hospitals, highways, railroads, and so on. In short, the essence of economic development is the creation of social and economic overhead capital. Decentralization and Regional autonomy provide an opportunity for the Government and local communities to develop independently because that's needed a change of attitude from the previously passive waiting command of the Central Government to be an initiative and innovative government (Yeung, 1996; Traistaru, 2004; Sihombing et al., 2017 \&Tamberi, 2007). Therefore, the new paradigm in implementing regional autonomy is how the regions realize good governance, by conducting reforms in the field of financial management and implementing of best practice. Economic Increase and its sustainable process are the main conditions for the sustainability of regional economic development. As the population continues to grow and means economic needs are also increasing (Nurlina and Muda, 2017). This can be achieved by increasing the aggregate output or Gross Regional Domestic Product every year. Spatial development in the sphere of the state is not always systemic. Some areas achieve rapid growth, while some other areas are experiencing slow growth. The regions do not experience the same progress due to the lack of resources owned, the tendency of the role of capital to choose an urban or regional area that already has facilities such as transportation infrastructure, electricity network, telecommunications network, banking, insurance, who are skilled in addition to the imbalance of redistribution of revenue sharing. Technological progress for most economists is the most important source of Economic Increase. In its simplest sense, technological progress occurs because of the discovery of new ways or improvements over old ways of handling traditional jobs such as growing corn, making clothes, or building homes (Resosudarmo, 2002). Recognize three classifications of technological 
progress, namely: neutral technological progress, labor-saving technological progress, and capital-saving technological progress.

Neutral technolohical progress occurs when the technology allows us to achieve higher levels of production by using the same number and combination of input factors. Simple innovations, such as the division of labor that can encourage increased output and increased consumption of society is an example. Meanwhile, technological advances can take place in such a way as to save capital or labor usage that is, the use of these technologies allows us to obtain higher output from the same amount of labor input or capital. The use of computers, automatic textile machines, high-speed electric drills, tractors and ground hijackers, and many other engine geniuses and other modern equipment, can be classified as labor-saving technological progress (Schafran et al., 2018). While the progress of capital-saving technology capital-saving technological progress is a rare phenomenon. This is because almost all research in the world of science and technology is done in the developed countries with the main goal of saving workers, and not saving capital (Mukhyi, 2005). Technological advances can also increase capital or labor. Labor-augmenting technological progress occurs when the application of technology can improve the quality or skill. For example, by using videotapes, televisions, and other electronic communication media in the classroom, the learning process biases more smoothly so that the absorption rate of the lesson material is also getting better. The advancement of technology that increases capital (Giannecchini and Taylor, 2018). this kind of progress occurs if the use of such technology allows us to capitalize on existing capital goods more productively. The use of wooden plows with steel plows in agricultural production (Syarifuddin, 2003).

In terms of conditions to improve the economy of a country, the emphasis is on the whole process in which the community develops from one stage to another. These different stages are intended to identify critical or strategic variables which are considered to be sufficient and necessary to change and transition to a new stage of quality. This theory is fundamentally unilinear and universal, and is considered permanent. Based on the analysis the stage takes off based on Rostow's theory as a transition period in which the community prepares itself to achieve self-sustained growth. The stage and after that economic growth will occur automatically. According to Rostow, the progress of the industrial sector has an important role in the transition period before reaching the stage of takeoff. Meanwhile the construction of infrastructure, according to Rostow, could spend a large part of investment funds (Xu et al., 2018). Investment in this infrastructure has 3 characteristics, namely the grace period between construction and picking up the results is very long, the construction must be carried out on a large scale so that it requires a lot of money, and the benefits of development are felt by many people. Based on this nature, infrastructure development must be carried out primarily by the government. In addition to the things stated above, Rostow also showed a form of change in government leadership from people who experienced transition. To ensure the creation of regular development, a new leadership must have the character of reactive nationalism, namely reacting positively to the pressures of developed countries. Rostow was convinced that without pressure or insults from developed countries, the modernization that took place in the Stage of Takeoff.

Industrial sector as the leading sector, it can be said that the country has experienced industrialization. industrialization as a transformation structural in a country (Landes, 2018). Therefore, the industrialization process can defined as the process of changing the economic structure where there is an increase industrial sector contribution to consumer demand, GDP, exports and opportunities work. Sector development manufacturing is the only choice, because this sector is capable of providing large jobs with more systematic remuneration compared to the primary and service industries (Yamada, 2018). The role of industry in the economy can be seen from its contribution to Gross Domestic Product (GDP), increased investment, employment, acquisition of net foreign exchange from export activities, formation of added value as well as contribution to taxes for the state.

\section{Literature Review}

\subsection{Rostow Theory}

Rostow's economic development theory was originally a Rostow article published in the Economics Journal (1956) and later developed further in his book entitled The Stages of Economic Growth (1960). The Rostow theory is grouped into a linear level model (Watkins, 1963 and Caceres-Carrasco et al., 2020). Rostow also made a distinction between the traditional sector and the modern capitalist sector. These phrases are known as "less developed" terminology, to refer to the condition of a country that still relies on the traditional sector, and "more developed" terminology to refer to the condition of a country that has reached the stage of industrialization by relying on the modern capitalist sector. In terms of the conditions for improving the economy of a country, the emphasis is on the whole process in which the community develops from one stage to another (Petrenko et al., 2018 and Liu, 2020). These different stages are intended to identify critical or strategic variables which are considered to be sufficient and 
necessary to change and transition to a new stage of quality. Rostow's theory is fundamentally unilinear and universal, and is considered permanent. According to Rostow, the process of economic growth can be divided into 5 stages (Khan, 2018). The 5 stages of economic growth according to Rostow are:

1. Traditional society,

2. Prerequisites for takeoff,

3. Take-off,

4. Towards maturity, and

5. The age of high mass consumption

The basis for differentiating the stages of economic development into five stages is the characteristic change in the economic, social and political conditions that occur. According to Rostow, economic development or the process of transforming a traditional society into a modern society is a multidimensional process (Seth, 2018 \& Jain and Koch, 2020). Economic development does not only mean a change in the economic structure of a country as indicated by the declining role of the agricultural sector and the increasing role of the industrial sector. According to Rostow, besides such changes, economic development also means a process that causes, among others: (Giannecchini \& Taylor, 2018)

1. Changes in the orientation of economic, political, and social organizations that were initially oriented to an area to be outward-oriented.

2. Changes in the views of the community regarding the number of children in the family, namely from wanting many children to become small families.

3. Changes in community investment activities, from making unproductive investments into productive investments.

4. Changes in life attitudes and customs that occur do not stimulate economic development.

The low contribution of industry to GDP indicates that the development of the sector so far has not been able to become a big helper towards the growth and development of other business sectors (Nakamura, 2018 and Sarkar, 2020). That condition too indicates that national industrial development has not been able to create efficient linkages between upstream and downstream sectors and between industries and sectors other economy.

\subsection{The Economic Increase}

Economic increase as a quantitative measure that illustrates the development of an economy in a given year when compared with the previous year. Economic increase is also the rate of growth formed from various indirect economic sectors describe the level of economic growth that occurs (Mizero, 2018). Economic increase is characterized the shift in work from relatively low activity productivity to higher activity. In other words growth the economy potentially tends to increase work productivity, and increase the scale of business units. Components forming economic growth include the accumulation of capital. Capital accumulation includes all new investments in land, physical equipment, and human resources. Capital accumulation occurs when part of community income is infested with the aim of increasing output (Kasza, 2018). New factories, machine tools, and materials increase physical capital stock a country and enables the achievement of increased output. Investation this productive must also be equipped with socio-economic infrastructure, namely: road, water, electricity, sanitation, communication and so on to support activities integrated economy.

\subsection{The Balanced Economic Structure}

The main target of the country's long-term development is the achievement of a balanced economic structure, namely the presence of capabilities and advanced industrial forces that are supported by strong agricultural capabilities and strengths. This means that between the agricultural and forestry sector and the industrial sector there is a need for strong linkages in both the future linkages and backward linkages in achieving the objectives of each sector (Steinmetz, 2018). The existence of this link can be seen from the development of agro-industry processing of agricultural products and agro-industry.

Agroindustry is a cross-disciplinary activity that utilizes natural resources for industry (Davletshina \& Khizbullina, 2020, Józefowska et al, 2020 and Tyapkina et al., 2020). Rostow also stressed that the increase in the level of investment might only be created if there is a change in the economic structure. Progress in the agricultural, mining and infrastructure sectors must occur together with the process of increasing investment. Economic development is only made possible by an increase in productivity in the agricultural sector and developments in the mining sector 
(Hai, 2019). According to Rostow, the progress of the agricultural sector has an important role in the transition period before reaching the stage of takeoff. Meanwhile the construction of infrastructure, according to Rostow, could spend a large part of investment funds.

Investment in the infrastructure sector has 3 characteristics, namely the grace period between construction and picking the results is long years, the construction must be carried out on a large scale so that it requires a lot of money, and the benefits of development are felt by many people (Chopde \& Gajbhiye, 2018, Germaschewski, 2020, Song et al., 2020 \& Yen et al., 2020). Based on this nature, infrastructure development must be carried out primarily by the government. In addition to the things stated above, Rostow also showed a form of change in government leadership from people who experienced transition. To ensure the creation of regular development, a new leadership must have a reactive nationalism that is reacting positively to the pressures of developed countries. Rostow believes that without pressure or insults from developed countries, the modernization that occurs Takeoff.

\subsection{Direction of Industrial Development Policy}

International competition is a new perspective for all countries, so the focus of future industrial development strategies is to build the competitiveness of a sustainable manufacturing industry on the international market. To build sustainable competitiveness. The essence of sustainable competitiveness lies in the effort to mobilize and organize all potential productive resources to produce innovative products that are cheaper, better, easier to obtain in order to meet market needs and demands (Bodrova and Kalinov, 2018). The manufacturing industry development strategy going forward by adapting the latest ideas that are currently developing, namely industrial development through a cluster approach in order to build sustainable industrial competitiveness. In the medium term, increasing industrial competitiveness is carried out by building and developing priority industrial clusters while in the long term more focused on integrating cluster approaches with efforts to manage demand (management demand) and build core competencies in each cluster.

The strategy for industrial development in the world in the future, adapts the latest thinking that is currently developing, which relates to the era of globalization and the development of 21 st century technology, namely the approach of industrial development through cluster concepts in the context of building sustainable industrial competitiveness (Mokyr, 2018 and Ooi et al., 2018). Basically industrial clusters are efforts to group core industries that are interconnected, both with supporting industries, related industries, supporting services, economic infrastructure, and related institutions. To determine a prospective industry, competitiveness, both the supply and demand side, is measured to see its ability to compete domestically and abroad (Qu and Lyu, 2019). The concept of international competitiveness, is a key word in the development of the industrial sector, therefore in addition to sectoral synergy, synergy with all business actors, as well as the entire region.

\section{Material and Methods}

Comparative causal research is a study directed to investigate cause-and-effect relationships based on observations of the consequences that occur and look for factors that cause through the data collected. In this study, the basic approach is to start with the differences of two groups. Comparative causal research is conducted in five stages: (1) formulating the problem, (2) determining the group that has the characteristics to be studied, (3) selection of comparison groups, (4) data collection, and (5) data analysis. Furthermore, in this study there are also some advantages and disadvantages when compared with other.

\section{Result and Discussion}

\subsection{Result}

The result of SmartPLS in the following Figure $1 \&$ Table 1: 


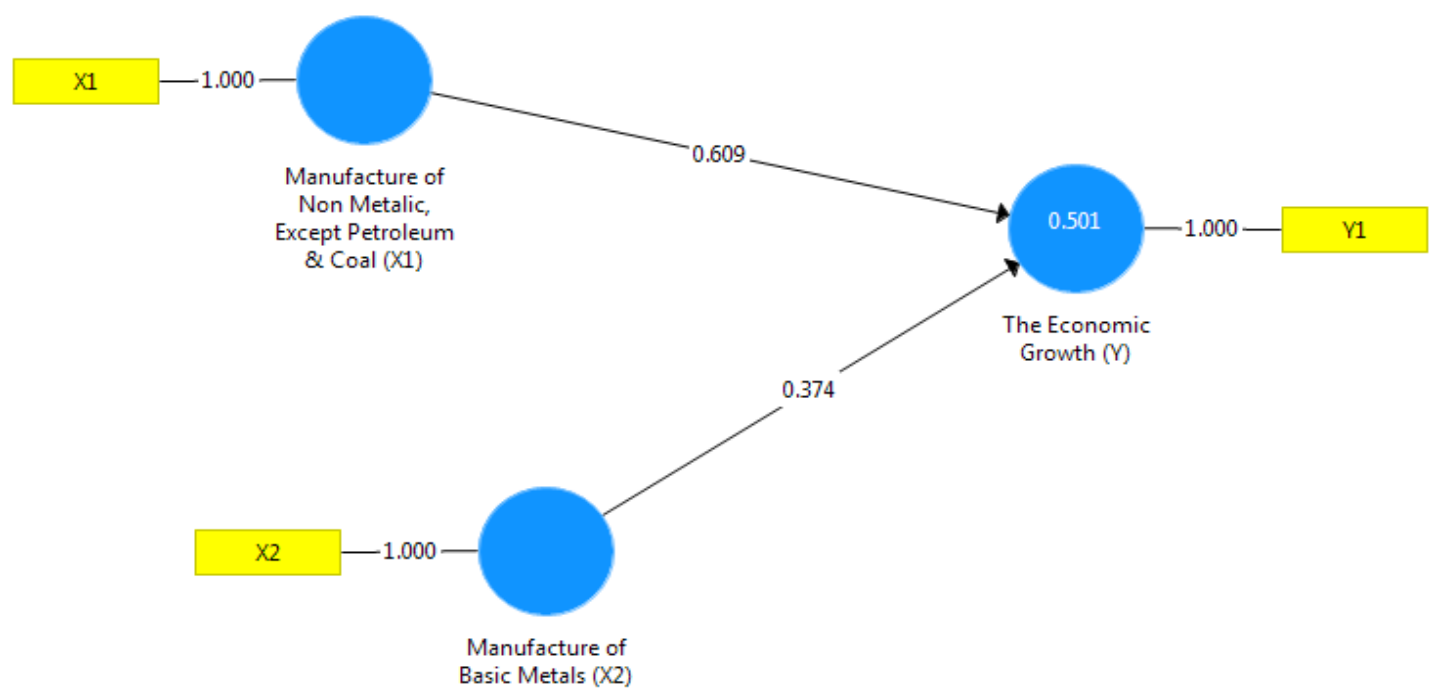

Figure 1. Overall Model

Sources: SmartPLS Result (2018).

Based on Figure 1 in graphically, the Manufacture of Non-Metallic, Except Petroleum \& Coal $\left(\mathrm{X}_{1}\right)$ variables that have an impact on the Economic Increase $(\mathrm{Y})$ and the Manufacture of Basic Metals $\left(\mathrm{X}_{2}\right)$ variable have no effect on the Economic Increase (Y). For the effect test can be seen in the following Table 1:

Table 1. The bootsraping

\begin{tabular}{lcc}
\hline & $t$ Statistics & $p$ Values \\
\hline Manufacture of Basic Metals $\left(\mathrm{X}_{2}\right)->$ The Economic Increase $(\mathrm{Y})$ & 1,533 & 0,126 \\
\hline $\begin{array}{l}\text { Manufacture of Non Metalic, Except Petroleum \& Coal }\left(\mathrm{X}_{1}\right)->\text { The } \\
\text { Economic Increase }(\mathrm{Y})\end{array}$ & 2,867 & 0,004 \\
\hline
\end{tabular}

Sources: SmartPLS Result (2018).

Based on the Table 1 results show that Manufacture of Non Metalic, Except Petroleum \& Coal are significant variables on The Economic Increase. The inner model evaluation is presented in the following Figure 2:

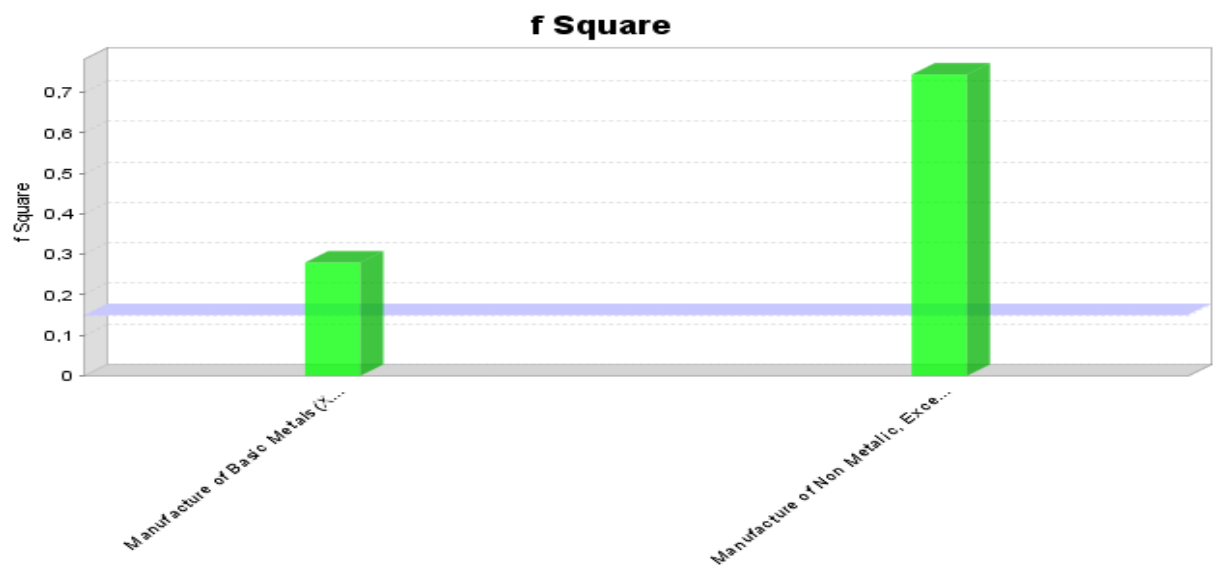

Figure 2. F Square

Sources: SmartPLS Result (2018). 
Based on Figure 2 shows that the dominant F Square value comes from the variable Manufacture of Non-Metallic, Except Petroleum \& Coal. For the adjuster R square show in the Table 2 as a follows:

Table 2. Adjusted R-Square Value

\begin{tabular}{lc}
\hline & Adjusted $\mathrm{R}^{2}$ \\
\hline The Economic Increase $(\mathrm{Y})$ & 0,425 \\
\hline
\end{tabular}

Sources: SmartPLS Result (2018).

Based on The Table 2 show that the variation of R-Square value of $50.1 \%$. The existence of Manufacture of Textiles, Clothing and Leather also has a great contribution on economic development of a region, because with the number of business unit workers that many will create jobs and be able to absorb labor so it has the potential to reduce unemployment in an area. GDP is the amount of gross value added that arises from all sectors of the economy in a region within a certain period.

\subsection{Discussion}

The definition of gross added value is the value of production (output) minus the cost between. Gross value-added components include the components of income factors (wages and salaries, interest, land rent and profits), net indirect depreciation and taxes. So calculating the gross added value of each sector and then adding it will produce the Gross Regional Domestic Product (GDP). Economic development with reference to the leading sector in addition to impacting the acceleration of Economic Increase will also affect the fundamental changes in economic structure (Bendavid, 1991; Basri, 2006 \& Bittencourt et al., 2006). The definition of superior sector is basically associated with a comparison form, be it international, regional and national comparison. In the international sphere, a sector is said to be superior if the sector is able to compete with the same sector with other countries. While in the national scope, a sector can be categorized as a leading sector if sectors in a certain region are able to compete with the same sector produced by other regions, either in national or domestic market (Amir and Singgih, 2005).

The determination of the leading sector becomes an important thing as the basis of regional development planning in accordance with the current era of regional autonomy, where the regions have the opportunity and authority to make policies in accordance with the regional potential to accelerate regional economic development for the improvement of people's prosperity. GDP data is very important information to know the output on the economic sector and see growth in a particular region. The leading sector is a group of sectors/sub-sectors able to encourage economic activity and create prosperity in a region mainly through production, export and job creation, so that the identification of the leading sectors is very important especially in order to determine the priorities and planning of economic development in the region. The benefits of knowing the leading sector, which is able to provide an indication for the economy nationally and regionally. The leading sector is certain to have greater potential to grow faster than other sectors in an area, especially the supporting factors of the leading sectors are capital accumulation, employment growth absorbed, and technological progress (Du and Park, 2006; Elmi, 2003). Creation of investment opportunities can also be done by empowering the potential of the leading sectors owned by the region concerned.

Quite often economic growth is not as expected by this economic theory. This is because economic growth is covered by population growth due to a decrease in mortality. The consequence is that a country becomes difficult to develop and through the stage of takeoff. The state must mobilize all of its capital and natural resources capabilities so as to achieve a productive investment level of $10 \%$ of its national income (Karreth, 2018). The effect of this theory is that there is a massive exploitation of natural resources and raw materials, without considering natural sustainability and sustainable development in the future. According to Rostow, economic development or the process of transforming a traditional society into a modern society is a multidimensional process. Economic development does not mean only changes in the economic structure of a country but also indicated by the role of the agricultural sector and the role of the industrial sector. According to Rostow, the economic development process can be divided into five stages, namely the traditional society, the preconditions for take-off, take-off, toward maturity, and the age of high mass consumption. According to Rostow that to reach the takeoff stage is not one economic sector that is standard for all countries that can create economic development. Therefore, a particular country cannot simply imitate the pattern of development in the leader sectors of other countries. 


\section{Conclusions}

The results show that Manufacture of Non Metalic, Except Petroleum \& Coal and Manufacture of Basic Metals influence to the Economic Increase. This study has limitations which are not analyzed with the approach of data pooling and cross section model so that the coefficients of each equation can be known each year so it can be known which has a big influence on Economic Increase. This research has implications for the government to provide facilities and facilities to investors who want to enter in the field of Manufacture of Non-Metalic, Except Petroleum $\&$ Coal and Manufacture of Basic Metals.

\section{References}

Ali, H., Abbas, M., \& Gill, M. U. T. (2018). Doctrine Values and Economic Advancement: A review of recent studies. Journal of Accounting and Applied Business Research, 1(2), 75-84.

Amir, H., \& Rifat, S. (2005). Sector Seed Analysis for Evaluation of Java Development Policy. Journal Finance and Monetary, 2(2), 80-93.

Basri, R. (2006). Analysis of Role of Agroindustry Sector on Revenue and Employment Opportunities in South Sulawesi. Economica Journal, 3(1), 25-38.

Bendavid. (1991). Regional and Local Economic Analysis for Practioners. London.

Bittencourt, M. V. L., Stanlay, R. T., \& Donald, W. L. (2006). An Examination of The Impact Exchange Rate Volatility on Sectoral Trade in The Mercosur. Paper Presented at the International Food and Agribusiness Management Association Annual Meeting, Buenos Aires, Argentina, June 10-11, 2006.

Bodrova, E. V., \& Kalinov, V. V. (2018). Russian Federation Scientific Adaptation Programs to the Market Economy and the Results of Their Implementation. Journal of History Culture and Art Research, 7(1), 103-112.

Caceres-Carrasco, F. R., Santos, F. J., \& Guzmán, C. (2020). Social capital, personal values and economic development: effect on innovation: An international analysis. Innovation: The European Journal of Social Science Research, 33(1), 70-95.

Central Bureau of Statistics. (2017). North Sumatera in Figures 2017. Republic of Indonesia. Jakarta.

Chopde, V., \& Gajbhiye, A. (2018). A study on relationship between total asset management and risk management in infrastructure industry of Nagpur City. TRANS Asian Journal of Marketing \& Management Research (TAJMMR), 7(5), 4-13.

Davletshina, Y., \& Khizbullina, R. (2020). Practice-Oriented Forms of Scientific and Technical Creativity of Gifted Youth. In "New Silk Road: Business Cooperation and Prospective of Economic Development" (NSRBCPED 2019) (pp. 645-647). Atlantis Press.

Du and Park, A. (2006). Blunting the Razor's: Regional Development in Reform China. Working Paper. University of Michigan.

Elmi, B. (2003). Study of Economic Improvement and Finance of North Lampung Regency 2002. Economic and Financial Review, 7(1), 34-45.

Germaschewski, Y. (2020). Stabilization policy, infrastructure investment, and welfare in a small open economy. Economic Modelling, 84, 322-339.

Giannecchini, P., \& Taylor, I. (2018). The eastern industrial zone in Ethiopia: Catalyst for development?. Geoforum, $88,28-35$.

Hai, N. M. (2019). Impacts of the Sectoral Transformation on the Economic Growth in Vietnam. In International Econometric Conference of Vietnam (pp. 1062-1072). Springer, Cham.

Jain, S., \& Koch, J. (2020). Crafting markets and fostering entrepreneurship within underserved communities: social ventures and clean energy provision in Asia. Entrepreneurship \& Regional Development, 32(1-2), 176-196.

Józefowska, A., Loaiza-Usuga, J. C., \& Schmidt, O. (2020). Consequences of land-use changes for soil quality and function, with a focus on the EU and Latin America. In Climate Change and Soil Interactions (pp. 207-228). Elsevier.

Karreth, A. K. (2018). Development in Theory and Practice: Culture, Ethnocentrism, and the Liberal Model. Polity, 50(4), 664-675. 
Kasza, G. J. (2018). Gerschenkron, Amsden, and Japan: The State in Late Development. Japanese Journal of Political Science, 19(2), 146-172.

Khan, B. Z. (2018). Human capital, knowledge and economic development: evidence from the British Industrial Revolution, 1750-1930. Cliometrica, 12(2), 313-341.

Landes, D. S. (2018). The fable of the dead horse; or, the Industrial Revolution revisited. In the British Industrial Revolution (pp. 128-159). Routledge.

Liu, Y. (2020). Research on Fiscal Expenditure Structure and High-Quality Economic Development: An Empirical Study Based on Panel Data from Chinese Provinces from 2007 to 2017. American Journal of Industrial and Business Management, 10(2), 232-249.

Lodde, S. (2007). Specialization and Concentration of The Manufacturing Industry in The Italian Local Labor Systems. Working Paper. Centro Ricerche Economiche Nord Sud. UniversitaDi Cagliari.

Mizero, O. (2018). Growth and development. Leading sector and institutions role in economic development: a case study of Botswana and Mauritius (Master's thesis, UiT Norges arktiske universitet).

Mokyr, J. (2018). The Economics of the Industrial Revolution (Routledge Revivals). Routledge.

Mukhyi, M. A. (2005). Analysis of the Role of Agricultural Sub-Sectors and the Sector of Superior to the Development of Economic Area of West Java Province: IRIO Analysis Approach. Economic and Development Journal, 2(1), 1-20.

Nakamura, D. (2018). A Role of Agglomeration Economies for a Self-Sufficient Regional Economy. In Locational Analysis of Firms' Activities from a Strategic Perspective (pp. 19-28). Springer, Singapore.

Nurlina, \& Muda, I. (2017). The Analysis of the Effects of Capital Expenditure and Human Development Index on Economic Growth and Poverty in East Aceh Regency. International Journal of Economic Research, 14(17), 415-428.

Ooi, K. B., Lee, V. H., Tan, G. W. H., Hew, T. S., \& Hew, J. J. (2018). Cloud computing in manufacturing: The next industrial revolution in Malaysia?. Expert Systems with Applications, 93, 376-394.

Petrenko, E., Pritvorova, T., \& Dzhazykbaeva, B. (2018). Sustainable Developmet Processes: Service Sector in Post-Industrial Economy. Journal of Security \& Sustainability Issues, 7(4).

Qu, S., \& Lyu, T. (2019). Does the Upgrading of Industrial Structure Mean Service Sector Is More Important?. In $A$ New Era (pp. 137-154). Palgrave Macmillan, Singapore.

Resosudarmo. (2002). Priority Sector Priority Analysis in Marine and Fisheries Indonesia. Jornal Coastal and Marine, 4(3), 17-28.

Saerofi, M. (2005). Economic Growth Analysis and Potential Sector Development in Semarang District (Approaches of Economic and SWOT Base Models). Faculty of Social Sciences University Negeri Semarang.

Sarkar, R. (2020). The Rule of Law: Theoretical Principles. In International Development Law (pp. 29-69). Springer, Cham.

Schafran, A., McDonald, C., Lopez Morales, E., Akyelken, N., \& Acuto, M. (2018). Replacing the services sector and three-sector theory: urbanization and control as economic sectors. Regional Studies, 1-12.

Seth, V. K. (2018). The Process of Transformation of Traditional Flexible Manufacturing into Industrial Revolution in Britain. In the Story of Indian Manufacturing (pp. 75-112). Palgrave Macmillan, Singapore.

Sihombing, M., Muda, I., Jumilawati, E., \& Dharsuky, A. (2017). Factors Affecting The Success of Local Innovation Systems with Government Programs As Moderators. International Journal of Economic Research, 14(21), 272-289.

Song, S., Diao, M., \& Feng, C. C. (2020). Urban mobility and resilience: Transport infrastructure investment and the demand for travel. In Building Resilient Neighbourhoods in Singapore (pp. 63-79). Springer, Singapore.

Steinmetz, J. D. (2018). Beyond Soviet and American models of industrialization: Aron's third way approach to global development. In Raymond Aron and International Relations (pp. 126-141). Routledge.

Syarifuddin, I. (2003). Study of Selection of Sub Sector of Excellence Service in Order to Support Bandung City as Service City. Infomatek Journal, 5(3), 99-112. 
Tamberi, M. (2007). Specialization and Growth Perspectives in the South Mediterranean Area. Dipartemento di Economia, Universita Politecnica delle Marche.

Traistaru, I. (2004). Sectoral Specialization, Trade Intensity and Business Cycle Synchronization in Enlarged EMU. Working Paper.

Tyapkina, M., Vinokurova, M., Vinokurov, S., \& Li, H. (2020). Development of Agroindustrial Companies: The Stakeholder Approach. In Regional Economic Development in Russia (pp. 101-112). Springer, Cham.

Watkins, M. H. (1963). A staple theory of economic growth. Canadian Journal of Economics and Political Science/Revue canadienne de economiques et science politique, 29(2), 141-158.

Xu, C., Pei, Q., Wong, V. K., Gu, C., \& Zhang, D. D. (2018). Western wind meets eastern soil: road to industrialization in China (1874-1927). Asian Geographer, 35(2), 161-175.

Yamada, T. (2018). Stage Theory or Typology?: Methodological Reflections on the Comparative Analysis of Capitalism. In Contemporary Capitalism and Civil Society (pp. 153-166). Springer, Singapore.

Yen, M. F., \& Li, Y. Y. (2020). Public Attitude Toward Investment in Sustainable Cities in Taiwan. In International Business, Trade and Institutional Sustainability (pp. 725-738). Springer, Cham.

Yeung, H. W. (1996). Sectoral Specialization and Competitive Advantage. ASEAN Economic Bulletin, July.

\section{Copyrights}

Copyright for this article is retained by the author(s), with first publication rights granted to the journal.

This is an open-access article distributed under the terms and conditions of the Creative Commons Attribution license (http://creativecommons.org/licenses/by/4.0/). 